\title{
Synthesized tetrahydroisoquinoline alkaloid exerts anticancer effects at least in part by suppressing NF-кB-regulated proteins in A549 human lung cancer cells
}

\author{
WON SUP LEE $^{1 *}$, JEONG WON YUN $^{1 *}$, ARULKUMAR NAGAPPAN $^{1}$, JING NAN LU $^{1,7}$, \\ MIN JEONG KIM ${ }^{1}$, JEONG-HEE LEE ${ }^{2}$, DONG HOON KIM ${ }^{3}$, YUNG HYUN CHOI ${ }^{6}$, \\ HYE JUNG KIM ${ }^{4}$, KI CHURL CHANG ${ }^{4}$ and JIN-MYUNG JUNG ${ }^{5}$ \\ Departments of ${ }^{1}$ Internal Medicine, ${ }^{2}$ Pathology, ${ }^{3}$ Emergency Medicine, ${ }^{4}$ Pharmacology and ${ }^{5}$ Neurosurgery, \\ Institute of Health Sciences, Gyeongsang National University School of Medicine, Jinju 660-702; \\ ${ }^{6}$ Department of Biochemistry, Dongeui University College of Oriental Medicine and Department of Biomaterial Control \\ (BK21 program), Dongeui University Graduate School, Busan 614-052, Republic of Korea
}

Received September 18, 2014; Accepted November 20, 2014

DOI: $10.3892 / o r .2014 .3658$

\begin{abstract}
CKD-712, a newly synthesized tetrahydroisoquinoline (THI) and an enantiomer ( $S$ form) of YS 49 (a derivative of higenamine) has been reported to suppress nuclear factor $-\kappa \mathrm{B}(\mathrm{NF}-\kappa \mathrm{B})$ activity in normal cells. In the present study, we investigated the anticancer effects of THI at a low concentration where CKD-712 did not induce cell death in normal cells. At the range of concentrations used, CKD-712 induced cell growth arrest, and inhibited the invasion and motility of A549 cells as determined by cell cycle analysis, a Matrigel-coated chamber assay, and a wound-healing assay, respectively. CKD-712 suppressed MMP-9, but not MMP-2 and other NF- $\kappa B$-regulated proteins involved in cancer metastasis such as VEGF. Moreover, CKD-712 induced cell cycle arrest at G2M phase by suppressing cyclin A, cyclin B and CDK-1 expression. Taken together, these data suggested that CKD-712 may exert anticancer effects by suppressing NF- $\mathrm{kB}$ pathways and inducing cell cycle arrest at G2M phase.
\end{abstract}

Correspondence to: Professor Won Sup Lee, Division of Hematology-Oncology Department of Internal Medicine, Gyeongsang National University College of Medicine, 90 Chiram-dong, Jinju 660-702, Republic of Korea

E-mail: lwshmo@hanmail.net or lwshmo@gnu.ac.kr

Dr Jin-Myung Jung, Department of Neurosurgery, Gyeongsang National University School of Medicine, 90 Chilam-dong, Jinju 660-702, Republic of Korea

E-mail: gnuhjjm@gnu.ac.kr

Present address: ${ }^{7}$ The Fifth Hospital of Shijiazhuang, Shijiazhuang, Hebei 050021, P.R. China

${ }^{*}$ Contributed equally

Key words: tetrahydroisoquinoline, MMP-9, NF-кB, cancer

\section{Introduction}

Phytochemicals have emerged as a promising therapeutic option in regulating cancer, as phytochemicals reportedly exhibit safety and enhance anticancer activity (1-3). The strategies for achieving anticancer effects from natural compounds have led to much interest. Thus attention has focused on the identification of new compounds with anticancer activities from natural compounds without evident toxicities, and the establishment of their precise mechanisms.

Tetrahydroisoquinoline (THI) alkaloids are derivatives of higenamine, a major component of Ranunculaceae that has been used as a herb for many diseases without reported toxicities. It has been reported that these alkaloids have pharmacological actions on inflammation. CKD-712, a newly synthesized THI and an enantiomer ( $S$ form) of YS 49 (a derivative of higenamine) has been reported to have anti-inflammatory activity by suppressing nuclear factor- $\mathrm{\kappa B}(\mathrm{NF}-\mathrm{\kappa B})$ in normal cells (4). NF- $\kappa B$ is a well-known transcription factor that is involved in cancer proliferation, invasion, and angiogenesis. In addition, NF- $\mathrm{KB}$ activation is closely associated with drug resistance by enhancing the transcription of anti-apoptotic proteins that interfere with death signaling. In that context, the agents harboring an inhibitory effect on NF- $\kappa B$ can have anticancer activities. This agent was developed for the cardiovascular disease, and has anti-inflammatory effects (5). Evidence suggested that inflammation is closely associated with carcinogenesis. In addition, previous findings suggested that THI alkaloids exert anticancer effects $(6,7)$. However, the anticancer effects of CKD-712 have not been reported yet. Therefore, we hypothesized CKD-712 possesses a certain anticancer property. In the present study, the anticancer effects of CKD-712 on A549 human lung cancer cells were examined.

\section{Materials and methods}

Cell culture and chemicals. A549 human lung adenocarcinoma cells from the ATCC (Rockville, MD, USA) were cultured 
in RPMI-1640 medium (Invitrogen, Carlsbad, CA, USA) supplemented with 10\% FBS (Gibco-BRL, Grand Island, NY, USA), $100 \mathrm{U} / \mathrm{ml}$ penicillin, and $100 \mu \mathrm{g} / \mathrm{ml}$ streptomycin in an incubator at $37^{\circ} \mathrm{C}$ in a humidified atmosphere of $95 \%$ air and $5 \% \mathrm{CO}_{2}$. Molecular mass markers for proteins were obtained from Pharmacia Biotech (Saclay, France). Antibodies against c-Myc, Bcl-2, Bcl-xL, XIAP, cIAP-1, cIAP-2, cyclin A, cyclin B, Cyclin-dependent kinase (CDK-1), VEGF, poly (ADP-ribose) polymerase (PARP), procaspase-3 and -9 , and NF- $\mathrm{\kappa B}$ (p65) were purchased from Santa Cruz Biotechnology, Inc. (Santa Cruz, CA, USA). Antibody against $\beta$-actin was from Sigma (Beverly, MA, USA). An enhanced chemiluminescence (ECL) kit was purchased from Amersham (Arlington Heights, IL, USA). Any other chemicals not specifically mentioned were purchased from Sigma Chemical Co., (St. Louis, MO, USA).

Cell proliferation assays. A549 cells were seeded in 24-well plates at a density of $5 \times 10^{4}$ cells $/ \mathrm{ml}$, grown to $70 \%$ confluence and then treated with the indicated concentrations of CKD-712 for $24 \mathrm{~h}$. Control cells were supplemented with media containing $0.1 \%$ DMSO (vehicle control). Cell viability was determined by the MTT assay.

Flow cytometric analysis. Cells $\left(2 \times 10^{5}\right)$ were plated in each well of six-well plates, and treated with the indicated concentration of CKD-712 (5-60 $\mu \mathrm{g} / \mu \mathrm{l})$ for $24 \mathrm{~h}$. The cells were washed twice with cold PBS and centrifuged at 1,200 rpm for $5 \mathrm{~min}$. The pellet was fixed in $75 \%(\mathrm{v} / \mathrm{v})$ ethanol for $1 \mathrm{~h}$ at $4^{\circ} \mathrm{C}$. The cells were washed once with PBS and resuspended in cold PI solution $(50 \mu \mathrm{g} / \mathrm{ml})$ containing RNase A $(0.1 \mathrm{mg} / \mathrm{ml})$ in PBS (pH 7.4) for $30 \mathrm{~min}$ in the dark. Flow cytometric analysis was performed using FACSCalibur (Becton Dickinson, San Jose, CA, USA).

Wound-healing assay. The cells were grown to $100 \%$ confluent monolayer and then scratched to form a $100 \mu \mathrm{m}$ 'wound' using sterile pipette tips. The cells were then cultured in the presence or absence of CKD-712 in serum-free media for $24 \mathrm{~h}$. The images were recorded at 12 and $24 \mathrm{~h}$ after scratching using an Olympus photomicroscope.

Cell invasion assay. The $5 \times 10^{4}$ cells $/ \mathrm{ml}$ cultured in serumfree media overnight were loaded onto pre-coated Matrigel 24-well invasion chambers (BD Biosciences, San Jose, CA, USA) with or without CKD-712. Then, $0.5 \mathrm{ml}$ of medium containing $20 \%$ FBS was added to the wells of the plate and incubated for $24 \mathrm{~h}$ at $37^{\circ} \mathrm{C}$ in $5 \% \mathrm{CO}_{2}$. The cells on the bottom of the Matrigel were fixed with $10 \%$ formalin, stained with DAPI, and counted. Stained nuclei were then observed under fluorescent microscope using a blue filter (magnification, $\mathrm{x} 400$ ).

Gelatin zymography. The gelatinolytic activities of the culture medium were assayed by electrophoresis with $10 \%$ polyacrylamide gels containing $1 \mathrm{mg} / \mathrm{ml}$ gelatin. Polyacrylamide gels were run at $120 \mathrm{~V}$, washed in $2.5 \%$ Triton X-100 for $1 \mathrm{~h}$, and then incubated for $16 \mathrm{~h}$ at $37^{\circ} \mathrm{C}$ in activation buffer (50 mM Tris-HCl, $\mathrm{pH} 7.5,10 \mathrm{mM} \mathrm{CaCl}{ }_{2}$ ). After staining with Coomassie blue (10\% glacial acetic acid, 30\% methanol and $1.5 \%$ Coomassie brilliant blue) for 2-3 $\mathrm{h}$, the gel was washed with a solution of $10 \%$ glacial acetic acid and $30 \%$ methanol for $1 \mathrm{~h}$. White lysis zones revealed by staining with Coomassie brilliant blue indicated gelatin degradation by MMP-2 and -9 .

Western blot analysis. The cells were gently lysed for $30 \mathrm{~min}$ with lysis buffer $(20 \mathrm{mM}$ sucrose, $1 \mathrm{mM}$ EDTA, $20 \mu \mathrm{M}$ Tris-HCl, pH 7.2, $1 \mathrm{mM}$ DTT, $10 \mathrm{mM} \mathrm{KCl}, 1.5 \mathrm{mM}$ $\mathrm{MgCl}_{2}, 5 \mu \mathrm{g} / \mathrm{ml}$ pepstatin A, $10 \mu \mathrm{g} / \mathrm{ml}$ leupeptin, and $2 \mu \mathrm{g} /$ $\mathrm{ml}$ aprotinin) to prepare the total protein Supernatants were collected and protein concentrations were determined using a Bio-Rad Protein Assay kit (Bio-Rad, Hercules, CA, USA). For the NF- $\mathrm{KB}$ (p65) experiment, cytoplasmic and nuclear proteins were extracted using nuclear and cytoplasmic extraction reagents according to the manufacturer's instructions. For the western blot analysis, an equal amount of protein was subjected to electrophoresis on sodium dodecyl sulfate (SDS)-polyacrylamide gels and transferred to a nitrocellulose membrane (Schleicher \& Schuell, Keene, NH, USA) by electroblotting. Blots were probed with the indicated antibodies. The membranes were then incubated with diluted enzyme-linked secondary antibodies for $1 \mathrm{~h}$ at room temperature. After washing, the membranes were developed by enhanced chemiluminescence.

Statistical analysis. Each experiment was performed in triplicate. The results were presented as the mean values \pm SD . Significant differences were determined using the Student's $\mathrm{t}$-test. Statistical significance was defined as $\mathrm{P}<0.05$.

\section{Results}

CKD-712 significantly suppresses cancer cell proliferation, but does not induce either apoptosis or cancer cell death in A549 lung cancer cells. According to a previous report, we used an amount $<100 \mu \mathrm{g} / \mathrm{ml}$ where CKD-712 did not show cyctotoxicity in the normal cells (5). We assessed the anticancer effects at a concentrations of 5-60 $\mu \mathrm{g} / \mathrm{ml}$ where the growth of A549 cells was not significantly suppressed. The MTT assay revealed that CKD-712 significantly suppressed cell proliferation in a dose-dependent manner (Fig. 1A). To confirm whether CKD-712 induces apoptosis, we performed DAPI staining and measured cells with sub- $\mathrm{G}_{1}$ DNA content. DAPI staining revealed that no definite apoptotic cell death (Fig. 1B). However, marked cell cycle changes were noted at the indicated concentrations of CKD-712 in $48 \mathrm{~h}$ (Fig. 1C). The increasing fraction of the cells with sub- $\mathrm{G}_{1}$ DNA content as CKD-712 was negligible. We assessed the anticancer effects of CKD-712 at the concentration of $30 \mu \mathrm{g} / \mathrm{ml}$. The MTT assay revealed that CKD-712 inhibited the cell proliferation up to $60 \%$, but did not induce caspase induction and PARP cleavages (Fig. 1D). This finding was confirmed by caspase inhibitors (Fig. 1E). These findings suggested that CKD-712 suppresses A549 cell proliferation, but CKD-712 did not induce apoptosis or any other type of cell death.

CKD-712 significantly suppresses cyclin $A$ and $B$ expression as well as CDC2 expression in A549 lung cancer cells. To investigate the molecular mechanisms for the $\mathrm{S}$ and G2M arrest, we assessed the expression levels of cyclin A, cyclin B, and CDK-1. Western blot analysis revealed that CKD-712 suppressed the expression of cyclin A, cyclin B, and CDK-1 


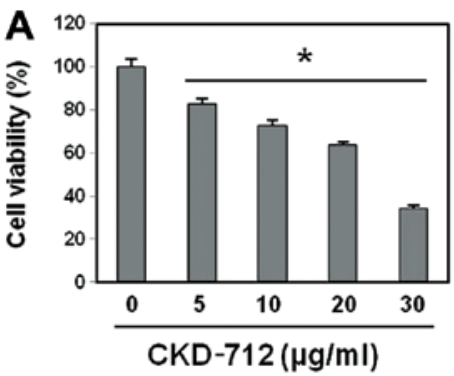

C
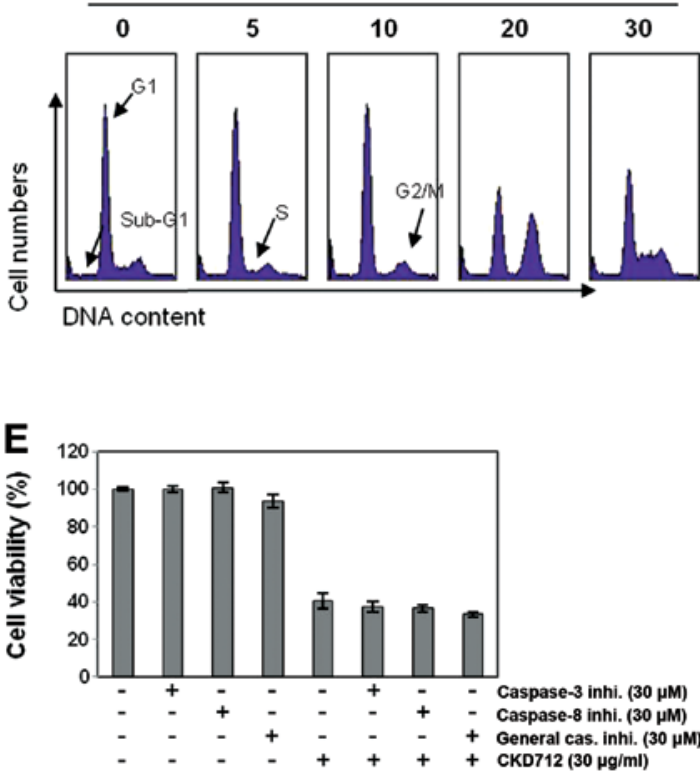
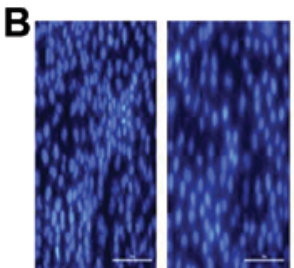

5

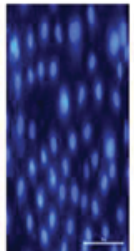

10

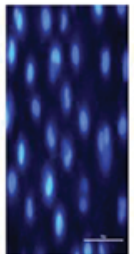

20

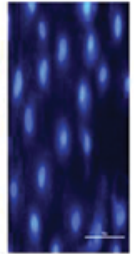

30

CKD-712 $(\mu \mathrm{g} / \mathrm{ml})$

D $\operatorname{CKD}-712(\mu \mathrm{M} / \mathrm{ml})$

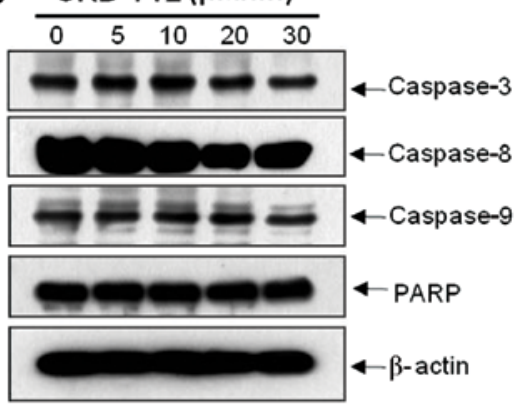

F $\operatorname{CKD}-712(\mu \mathrm{M} / \mathrm{ml})$

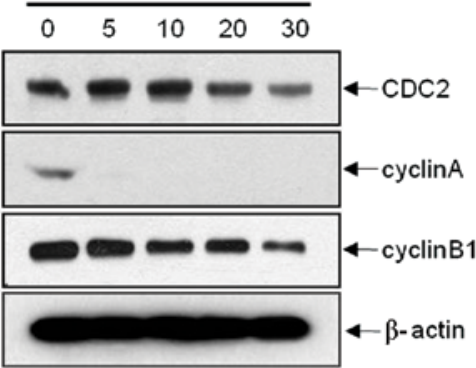

Figure 1. Anti-proliferative activity of CKD-712 in A549 human lung cancer cells. The cells were seeded at a density of 5x10 4 cells/ml. Cell growth inhibition was measured by MTT assay. The cells were treated with the indicated concentrations of CKD-712 for $48 \mathrm{~h}$. (A) Cell viability was assessed by the MTT assay. The growth inhibition and cytotoxicity CKD-712 are shown at the indicated concentrations. (B) After fixation, the cells were stained with DAPI solution to observe apoptotic body. Stained nuclei were then observed under fluorescent microscope using a blue filter (magnification, $\mathrm{x} 400$ ). (C) Using flow cytometry, the cells with sub- $\mathrm{G}_{1}$ DNA content representing the cells undergoing cell death were also analyzed. (D and F) Equal amounts of cell lysate (30 $\mu$ g) were resolved by SDS-polyacrylamide gels and transferred onto nitrocellulose membranes. The membranes were probed with the indicated antibodies. The proteins were visualized using an ECL detection system. $\beta$-actin was used as an internal control. (E) Cell viability was assessed using the MTT assay. The data are shown as the mean \pm SD values of three independent experiments. ${ }^{*} \mathrm{P}<0.05$ between the treated and untreated control group.

(Fig. 1F), suggesting that suppression of the expression of cyclin A, cyclin B, and CDK-1 is one of the mechanisms for CKD-712-induced cell cycle arrest.

CKD-712 inhibits the invasion as well as migration of A549 lung cancer cells. Cancer cell invasion is the key event in metastasis, thus we performed the invasion test to determine the anticancer effects of CKD-712 on A549 cells in vitro. CKD-712 inhibited cell invasion in a dose-dependent manner as measured by Matrigel invasion assays (Fig. 2A). In addition, CKD-712 inhibited cancer cell migration in the wound-healing assay at a concentration of $20 \mu \mathrm{g} / \mathrm{ml}$ (Fig. 2B). These findings suggest that CKD-712 effectively suppressed A549 cell invasion and migration.

CKD-712 inhibits the expression of MMP-9 in A549 lung cancer cells, but not MMP-2. To investigate the changes at the molecular level, we assessed the expression levels of MMP-2 and -9, which are key molecules for cancer invasion involved in by the proteolytic digestion of the extracellular matrix (ECM) $(8,9)$. The activities of MMP-2 and -9 secreted in media using gelatin zymography analyses were measured, which revealed that CKD-712 predominantly suppressed the expression of $M M P-9$ gene in a dose-dependent manner, whereas no changes were identified in MMP-2 expression (Fig. 2C). These data suggested that CKD-712 inhibits A549 cell invasion at least in part by suppressing MMP-9.

CKD-712 suppresses $N F-\kappa B$ activity, and $N F-\kappa B$-regulated proteins involved in cancer proliferation, and angiogenesis in A549 lung cancer cells. The NF- $\mathrm{KB}$ pathway is involved in cancer cell proliferation, invasion, and metastasis $(10,11)$. MMP-9 expression is preferentially regulated by $\mathrm{NF}-\kappa \mathrm{B}(12)$. We hypothesized that the stimulatory effects of TNF on invasion and MMP-9 expression were driven by NF- $\kappa \mathrm{B}$ activation. In addition, we previously suggested that CKD-712 suppressed $\mathrm{NF}-\kappa \mathrm{B}$ activation in normal cells (5). In the present study, we investigated again whether CKD-712 inhibits NF- $\kappa \mathrm{B}$ activation using western blot analysis, which revealed that TNF enhanced $\mathrm{NF}-\kappa \mathrm{B}$ translocation into the nucleus and CKD-712 inhibited 

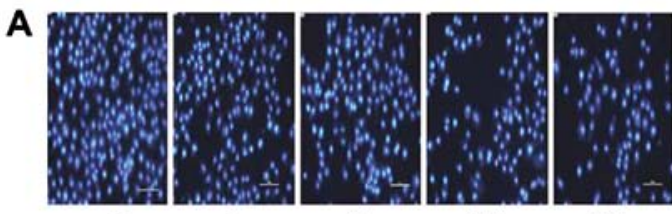

30

CKD-712 $(\mu \mathrm{g} / \mathrm{ml})$

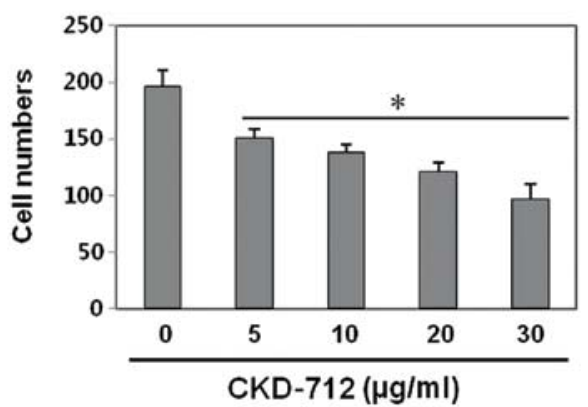

C

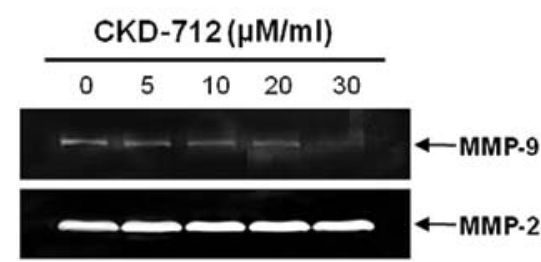

B

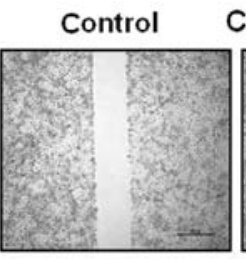

CKD $-71220 \mu \mathrm{g} / \mathrm{ml}$

$12 \mathrm{~h}$
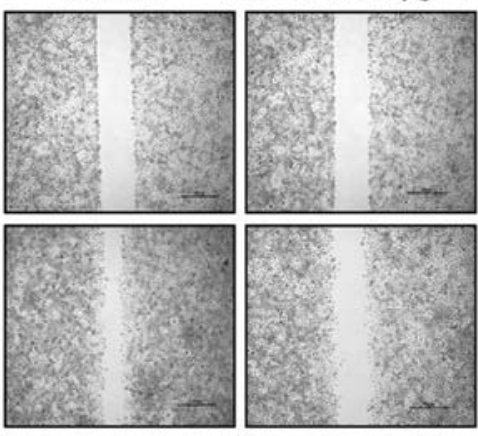

$24 \mathrm{~h}$
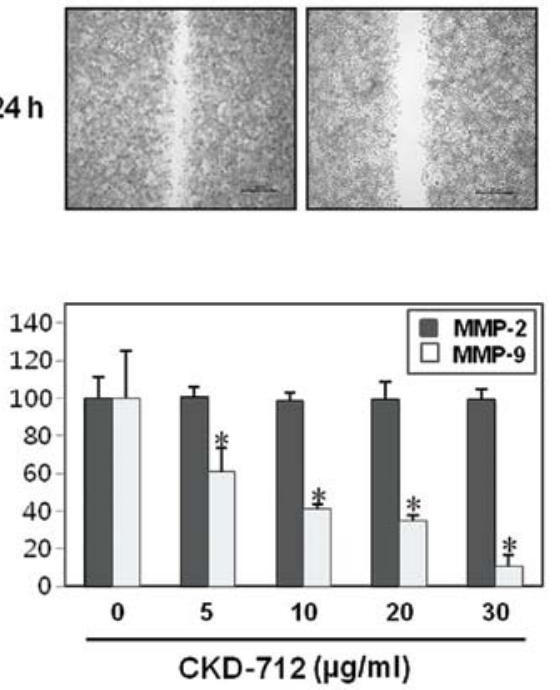

Figure 2. A dose-dependent inhibitory effect of CKD-712 on the invasion of A549 human lung cancer cells. (A) Effects on invasion of A549 cells. A549 cells were treated with CKD-712 $(0-60 \mu \mathrm{g} / \mathrm{ml})$ for $18 \mathrm{~h}$ in a Matrigel-coated Transwell assay. The Matrigel invasion chambers were incubated for $24 \mathrm{~h}$. P $<0.05 \mathrm{vs}$. control. (B) Cells were grown to $100 \%$ confluency on $30-\mathrm{mm}$ cell culture dishes coated with collagen and then serum-starved for $24 \mathrm{~h}$ with or without CKD-712 for $24 \mathrm{~h}$. After creating a linear scratch with a pipette tip, serum-free media with or without CKD-712 was added. Images of the etched area in a Petri dish were captured at intervals of 0,12 and $24 \mathrm{~h}$. Data were representative of three independent experiments. (C) Secreted MMP-2 and -9 proteins measured by gelatin zymography. Cells were incubated for $24 \mathrm{~h}$ with CKD-712 $(0-400 \mu \mathrm{g} / \mathrm{ml})$. Values are presented as the means \pm SD from three independent experiments. ${ }^{*} \mathrm{P}<0.05$ vs. control.

the TNF-induced NF- $\kappa \mathrm{B}$ activation. Additionally, the inhibitory effects on TNF-induced $\mathrm{NF}-\kappa \mathrm{B}$ activation were not as marked as that shown in the cells treated with CKD-712 alone (Fig. 3A). We measured the levels of NF- $\mathrm{BB}$-regulated proteins associated with cancer proliferation, invasion, angiogenesis, and anti-apoptosis in A549 cells. We found that CKD-712 suppressed NF- $\mathrm{BB}$-regulated proteins involved in cancer cell proliferation (c-Myc and COX-2), anti-apoptosis (Bcl-xL, XIAP, cIAP1, cIAP2), and angiogenesis (VEGF) (Fig. 3B). These gene products are known to be regulated by $\mathrm{NF}-\kappa \mathrm{B}$, thus we investigated the effect of CKD-712 on these molecules. Western blot analysis revealed that CKD-712 suppressed these proteins. The results suggested that CKD-712 may suppress MMP-9 as well as other NF- $\kappa$ B-regulated proteins that have been associated with cancer metastasis.

\section{Discussion}

The aim of the present study was to investigate the anticancer effects of CKD-712 on human lung cancer cells and, to determine whether CKD-712 exerts anticancer effects at the doses where the anti-inflammatory effects were shown (5). A previous report demonstrated that CKD-712 has suppressive effects on the activated NF- $\kappa \mathrm{B}$ in normal cells (5). We found that CKD-712 suppressed cancer cell invasion and migration through suppression of MMP-9 at the concentration where cytotoxicity was not evident in normal cells. Invasion is the first step of cancer metastasis, for which the process includes proteolytic digestion of the ECM, and cell migration through the basement membranes to reach the circulatory system. In particular, MMP-2 (gelatinase-A) and MMP-9 (gelatinase-B) are important in the proteolytic digestion of the basement membrane. We clearly demonstrated that CKD-712 had inhibitory activities by suppressing the expression of MMP-9 in A549 cells. Gelatin zymography showed that CKD-712 predominantly suppressed MMP-9 expression compared to MMP-2. This finding can be supported by previous studies showing that MMP-9 appeared to be much more influenced by NF- $\kappa$ B activation than was the case for MMP-2 $(13,14)$, and MMP-9 promoter contains $\mathrm{NF}-\kappa \mathrm{B}$ binding sites (12). In addition, we have demonstrated that CKD-712 inhibited VEGF, which is important in cancer neovascularization and angiogenesis. Natural compounds (15) or dietary agents (16) carrying anti$N F-\kappa B$ activity have also shown similar effects on cancer cells although the dominant target was different. 
A

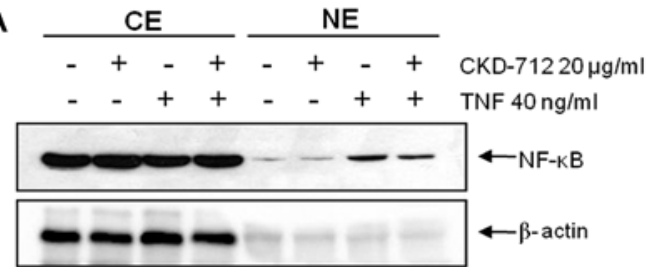

B

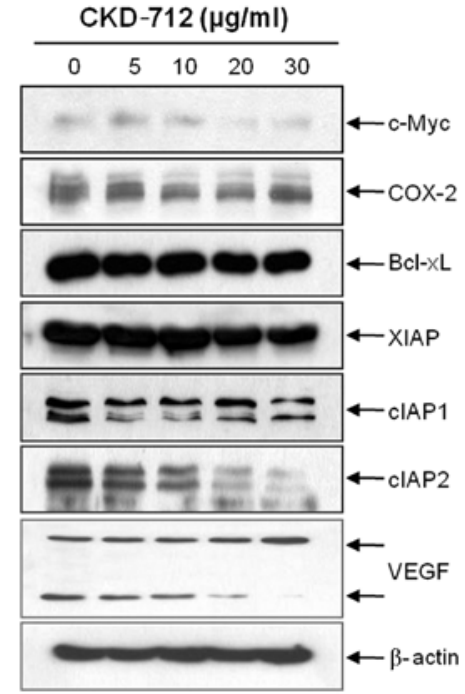

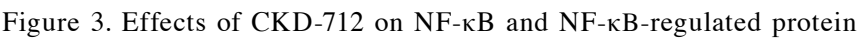
(A) Inhibitory effects of CKD-712 on TNF- $\alpha$-induced NF- $\mathrm{KB}$ translocation into the nucleus. Cells were pretreated with CKD-712 $(1 \mu \mathrm{M})$ for $1 \mathrm{~h}$ and then treated with TNF- $\alpha(10 \mathrm{ng} / \mathrm{ml})$ for $30 \mathrm{~min}$. Following treatment, nuclear and cytoplasmic fractions were extracted from total cell lysates and protein levels were determined by western blot analysis. (B) Cells were treated with CKD-712 for $24 \mathrm{~h}$ at the indicated concentration. Whole-cell extracts were prepared, and $30 \mu \mathrm{g}$ of the whole-cell lysate was analyzed by western blot analysis using antibodies against various NF- $\mathrm{kB}$-regulated proteins involved in cancer cell proliferation (c-Myc and Cox-2), anti-apoptosis (Bcl-xL, XIAP, cIAP1 and cIAP2), and angiogenesis (VEGF). Data are representative of two independent experiments.
The present result have shown that CKD-712 inhibited $\mathrm{NF}-\kappa \mathrm{B}$ activity and NF- $\kappa \mathrm{B}-$ regulated proteins involved in cancer survival and proliferation. The primary role of TNF consists in the regulation of immune cells, and TNF was able to induce interleukin (IL) production, apoptotic cell death, and inflammation to inhibit tumorigenesis. TNF induces cell death through the extrinsic pathway in certain cancer cells (13). However, most cancer cells are resistant to TNF-induced cell death by activation of NF- $\mathrm{KB}$ followed by the enhanced transcription of anti-apoptotic proteins that interfere with cell death signaling (14). Moreover, paradoxically the patients with advanced and metastatic cancers have higher serum levels of TNF than those with early stage cancer (12) that are associated with cancer progression $(12,15)$. Therefore, NF- $\mathrm{kB}$ can a good therapeutic target for the treatment of advanced cancer. We hypothesized that if NF- $\mathrm{\kappa B}$ is suppressed by less toxic drugs, TNF induces apoptosis of cancer cells. This may prove to be an alternative approach for the treatment of patients with metastasis or advanced patients without showing serious side effects. Thus, we investigated the anticancer effects of CKD-712 with a special focus on NF- $\mathrm{KB}$ and the NF- $\kappa \mathrm{B}-$ regulated gene which is involved in cancer progression and metastasis.

The study has certain limitations. First is that we did not clearly examine the mechanisms by which CKD-712 manifests its other anticancer effects such as cell cycle arrest. Most of the agents with anti-NF- $\mathrm{kB}$ activity were associated with cyclin D1 suppression $(17,18)$. Therefore, cell cycle arrest by CKD-712 was considered a distinct anticancer activity. Another limitation is that we did not fully elucidate the reason for CKD-712 not exerting prominent anticancer effects in terms of apoptosis. Further study is required to elucidate the underlying mechanisms.

In conclusion, this study suggests that CKD-712 exerts anticancer effects at least in part by inhibiting NF- $\kappa B$ activation and downstream proteins (Fig. 4). CKD-712-induced cell

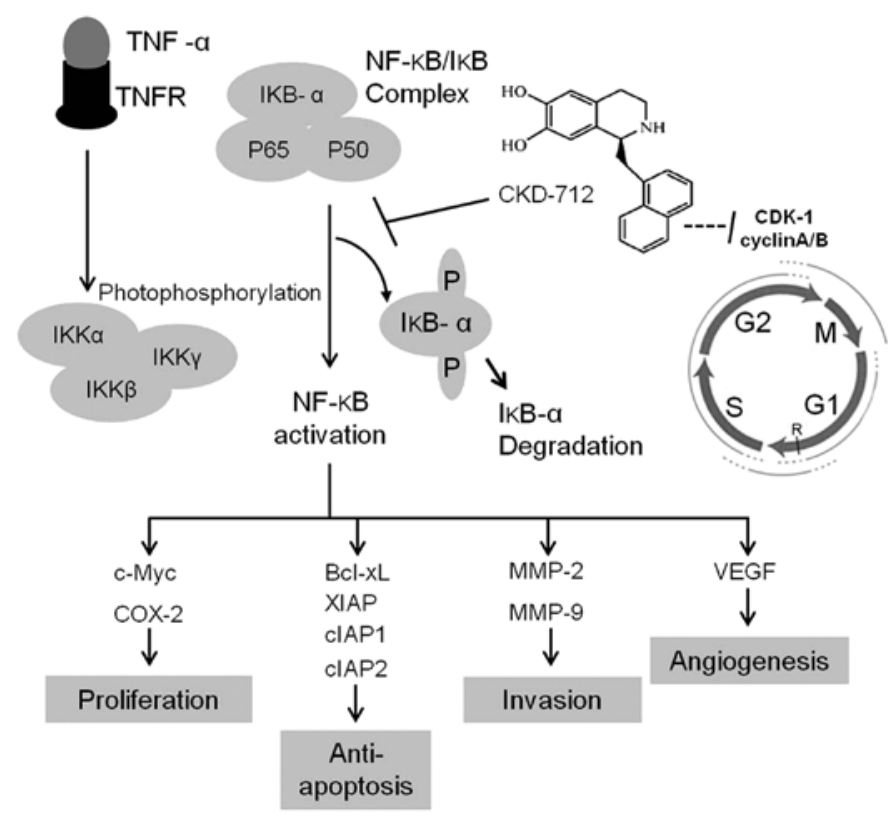

Figure 4. Schematic representation of the anticancer effects of CKD-712 on A549 human lung cancer cells. Following activation of NF- $\mathrm{kB}$ pathways, CKD-

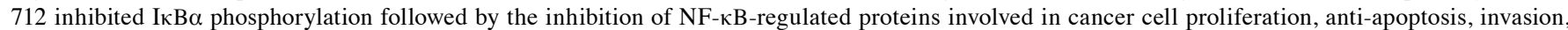
and angiogenesis. In addition, CKD-712 induces G2M cell cycle arrest by suppressing cyclin A and B and CDK-1. Taken together, these data suggested that CKD-712 may exert anticancer effects by suppressing NF-kB pathways and inducing cell cycle arrest at G2M phase. 
cycle arrest is another mechanism for these anticancer effects. This study therefore provides evidence that CKD-712 may exert anticancer effects on human lung cancer.

\section{Acknowledgements}

This study was supported by a grant of the National R\&D Program for Cancer Control (0820050), Ministry for Health, Welfare and Family Affairs.

\section{References}

1. Liu BL, Zhang X, Zhang W and Zhen HN: New enlightenment of French Paradox: resveratrol's potential for cancer chemoprevention and anti-cancer therapy. Cancer Biol Ther 6: 1833-1836, 2007.

2. Hatcher H, Planalp R, Cho J, Torti FM and Torti SV: Curcumin: from ancient medicine to current clinical trials. Cell Mol Life Sci 65: 1631-1652, 2008.

3. Kundu JK and Chun KS: The promise of dried fruits in cancer chemoprevention. Asian Pac J Cancer Prev 15: $3343-$ 3352, 2014.

4. Jin YC, Lee YS, Kim YM, Seo HG, Lee JH, Kim HJ, et al: (S)-1-(alpha-naphthylmethyl)-6,7-dihydroxy-1,2,3,4tetrahydroisoquinoline (CKD712) reduces rat myocardial apoptosis against ischemia and reperfusion injury by activation of phosphatidylinositol 3-kinase/Akt signaling and anti-inflammatory action in vivo. J Pharmacol Exp Ther 330: 440-448, 2009.

5. Tsoyi K, Kim HJ, Shin JS, Kim DH, Cho HJ, Lee SS, et al: HO-1 and JAK-2/STAT-1 signals are involved in preferential inhibition of iNOS over COX-2 gene expression by newly synthesized tetrahydroisoquinoline alkaloid, CKD712, in cells activated with lipopolysacchride. Cell Signal 20: 1839-1847, 2008.

6. Tabunoki H, Saito N, Suwanborirux K, Charupant K and Satoh J: Molecular network profiling of U373MG human glioblastoma cells following induction of apoptosis by novel marine-derived anti-cancer 1,2,3,4-tetrahydroisoquinoline alkaloids. Cancer Cell Int 12: 14, 2012.
7. Yap TA, Cortes-Funes H, Shaw H, Rodriguez R, Olmos D, Lal R, et al: First-in-man phase I trial of two schedules of the novel synthetic tetrahydroisoquinoline alkaloid PM00104 (Zalypsis) in patients with advanced solid tumours. Br J Cancer 106: 1379-1385, 2012.

8. Davies B, Waxman J, Wasan H, Abel P, Williams G, Krausz T, et al: Levels of matrix metalloproteases in bladder cancer correlate with tumor grade and invasion. Cancer Res 53: $5365-5369,1993$.

9. Bogenrieder T and Herlyn M: Axis of evil: molecular mechanisms of cancer metastasis. Oncogene 22: 6524-6536, 2003.

10. Aggarwal BB: Nuclear factor-kappaB: the enemy within. Cancer Cell 6: 203-208, 2004.

11. Gilmore TD: Introduction to NF-kappaB: players, pathways, perspectives. Oncogene 25: 6680-6684, 2006.

12. Rangaswami H, Bulbule A and Kundu GC: Nuclear factorinducing kinase plays a crucial role in osteopontin-induced MAPK/IkappaBalpha kinase-dependent nuclear factor kappaBmediated promatrix metalloproteinase-9 activation. J Biol Chem 279: 38921-38935, 2004.

13. Cheng CY, Hsieh HL, Hsiao LD and Yang CM: PI3-K/Akt/ $\mathrm{JNK} / \mathrm{NF}-\kappa \mathrm{B}$ is essential for MMP-9 expression and outgrowth in human limbal epithelial cells on intact amniotic membrane. Stem Cell Res 9: 9-23, 2012

14. Hozumi A, Nishimura Y, Nishiuma T, Kotani Y and Yokoyama M: Induction of MMP-9 in normal human bronchial epithelial cells by TNF-alpha via NF-kappa B-mediated pathway. Am J Physiol Lung Cell Mol Physiol 281: L1444-L1452, 2001.

15. Yun JW, Lee WS, Kim MJ, Lu JN, Kang MH, Kim HG, et al: Characterization of a profile of the anthocyanins isolated from Vitis coignetiae Pulliat and their anti-invasive activity on HT-29 human colon cancer cells. Food Chem Toxicol 48: 903-909, 2010.

16. Ji AJ, Liu SL, Ju WZ and Huang XE: Anti-proliferation effects and molecular mechanisms of action of tetramethypyrazine on human SGC-7901 gastric carcinoma cells. Asian Pac J Cancer Prev 15: 3581-3586, 2014.

17. Sun Z and Andersson R: NF-kappaB activation and inhibition: a review. Shock 18: 99-106, 2002.

18. Aggarwal BB and Sung B: NF-кB in cancer: a matter of life and death. Cancer Discov 1: 469-471, 2011. 